\title{
Characterization of angiotensin-converting enzyme in canine testis
}

\author{
K. Sabeur, A. T. Vo and B. A. Ball* \\ Department of Population Health and Reproduction, 1114 Tupper Hall, University of \\ California, Davis, CA 95616, USA
}

The aim of this study was to characterize angiotensinconverting enzyme (ACE) in canine testis. Detergentextracted canine testes were sonicated in the presence of protease inhibitors and purified on an affinity column with the ACE inhibitor, lisinopril, as an affinity ligand for ACE. The fractions recovered were assessed for ACE enzyme activity via an enzyme kinetic microplate assay (at $330 \mathrm{~nm}$ ) based on the hydrolysis of Fa-Phe-Gly-Gly (FAPGG) at pH 7.5 during an $8 \mathrm{~min}$ incubation. The specific activity of ACE in the starting testicular extracts was $3.53 \pm 0.99 \mathrm{mU} \mathrm{mg}^{-1}$ protein with a 1588 times enrichment in ACE activity after lisinopril affinity chromatography $\left(4239 \pm 2600 \mathrm{mU} \mathrm{mg}^{-1}\right.$ protein). The recovery efficiency of ACE after lisinopril affinity chromatography was $71.2 \%$. The ACE activity in the detergent extracts and the purified fractions was inhibited significantly by $10 \mu \mathrm{mol}$ captopril $\mathrm{I}^{-1}$, a specific ACE inhibitor, and was restored to $88 \%$ of normal activity by the addition of the thiol-alkylating agent $\mathbf{N}$-ethylmaleimide $\left(0.5 \mathrm{mmol} \mathrm{I}^{-1}\right)$ in the detergent extracts and the purified fractions incubated with captopril. The treatment of testicular extracts with $10 \mathrm{mmol}^{\text {EDTA }} \mathrm{I}^{-1}$ reduced the ACE activity significantly $(5.40 \pm 1.26$ versus $0.58 \pm 0.23 \mathrm{mU}$ $\mathrm{mg}^{-1}$ ). The ACE activity was restored fully in the presence of zinc $\left(5.28 \pm 0.70 \mathrm{mU} \mathrm{mg}{ }^{-1}\right)$. The anti-ACE antibody (raised against a $70 \mathrm{kDa}$ protein from the periacrosomal plasma membrane of equine spermatozoa) recognized a 65-70 kDa protein in the detergent-extracted testes as well as in the affinity-purified fractions. This antibody also recognized a protein of similar molecular mass in ejaculated spermatozoa. ACE was localized in the periacrosomal area of the ejaculated spermatozoa and in spermatids in the seminiferous tubules. The results of this study demonstrate that ACE is present in canine testis and retains its enzyme activity after purification with lisinopril affinity chromatography. Activity of canine ACE is inhibited by captopril and EDTA and is restored in the presence of $\mathrm{N}$-ethylmaleimide and zinc.

\section{Introduction}

Angiotensin-converting enzyme (ACE) is a zinc-metallopeptidase that typically cleaves C-terminal dipeptides from several oligopeptide substrates, including angiotensin I and bradykinin. Although this enzyme is associated most commonly with the regulation of blood pressure, there is considerable evidence for the potential role of ACE in reproductive function (Schill and Miska, 1992; Kohn et al., 1995; Esther et al., 1996). The gene for ACE codes for both a somatic and a smaller testis-specific isozyme. The somatic ACE is expressed widely in the body; it is anchored to the plasma membrane of vascular endothelial cells and epithelial cells, including cells in the epididymis. Macrophages and Leydig cells in the testis also express this isozyme. In contrast, the germinal isozyme is unique to the testis, which expresses both isoenzymes at a ratio of 4:1 (germinal:somatic) (Lanzillo et al., 1985). Transcription of testis ACE begins in late pachytene spermatocytes

*Correspondence

Email: baball@ucdavis.edu
(Langford et al., 1993) or after meiosis (Sibony et al., 1994). The germinal isozyme is expressed exclusively in postmeiotic spermatogenic cells (late spermatids) and mature spermatozoa (Langford et al., 1993; Hagaman et al., 1998; Kohn et al., 1998). Although the physiological functions of ACE in the reproductive system are not well established, there is evidence that it has a role in fertility. The fertility of male mice deficient in both somatic and testicular ACE was greatly reduced (Krege et al., 1995; Esther et al., 1996, 1997). A $70 \mathrm{kDa}$ protein from the periacrosomal plasma membrane of equine spermatozoa has been isolated, which shows homology to ACE based on microsequence analysis of a peptide fragment (Dobrinski et al., 1997).

In the present study, the use of lisinopril, a specific ACE inhibitor, for affinity chromatography of testicular canine ACE is reported and the substrate specificity of the enzyme and the zinc requirement for its activity are described. The presence of ACE in ejaculated canine spermatozoa and in spermatids in canine seminiferous tubules is also demonstrated. 


\section{Materials and Methods}

\section{Materials}

Lisinopril, captopril, N-(3-[2-Furyl]acryloyl-Phe-Gly-Gly (FAPGG), phenylmethylsulphonyl fluoride (PMSF), pepstatin, leupeptin, antipain, N-ethylmaleimide EDTA, Triton-X100, zinc acetate and fluorescein isothiocyanateconjugated (FITC) goat anti-rabbit IgG were purchased from Sigma Chemical (St Louis, MO). The silver staining kit, electrophoretic markers and horseradish peroxidaseconjugated secondary antibody were purchased from BioRad (Hercules, CA). Sodium borate was from Fisher Scientific (Tustin, CA). The enhanced chemiluminescence (ECL) detection kit was from Amersham Pharmacia Biotech (Piscataway, NJ).

\section{Purification of testis ACE using a lisinopril affinity column}

Testicular tissue extraction. Frozen canine testes were obtained with the permission of the owner and after castration of client animals presented to the Veterinary Medical Teaching Hospital of the University of California, Davis. Tissues were stored at $-70^{\circ} \mathrm{C}$ before isolation of ACE. The tissues $(20 \mathrm{~g})$ were cut into small pieces $(1 \mathrm{~cm} \times 1 \mathrm{~cm})$ and homogenized in $50 \mathrm{ml}$ Tris buffer, $\mathrm{pH} 7.4$ using a blender (UltraTurrex 95, $13500 \mathrm{rpm}$ ) for five $\times 15 \mathrm{~s}$. Protease inhibitors were added immediately to the Tris buffer: PMSF $\left(500 \mu \mathrm{mol} \mathrm{I}^{-1}\right)$, pepstatin $(1 \mu \mathrm{mol} \mathrm{I-1})$, leupeptin $\left(5 \mu \mathrm{mol} \mathrm{I} \mathrm{I}^{-1}\right)$ and antipain $\left(25 \mu \mathrm{mol} \mathrm{I}^{-1}\right)$ (final concentrations). The homogenized sample was passed through cheesecloth and centrifuged twice at $20000 \mathrm{~g}$ for $30 \mathrm{~min}$ (Pantaliano et al., 1984). The resulting pellet was suspended in 6-10 $\mathrm{ml}$ Tris buffer with all the protease inhibitors and Triton-X100 was added to a final concentration of $1 \%(\mathrm{v} / \mathrm{v})$. The solution was mixed overnight in a cold room. The suspension was sonicated using six pulses (15 s each) of a sonic dismembrator 60 (Fisher Scientific). The sonicated membrane was then centrifuged at $45000 \mathrm{~g}$ for $60 \mathrm{~min}$. The supernatant containing the solubilized protein was stored at $-20^{\circ} \mathrm{C}$.

Affinity chromatography. A prepacked N-hydroxysuccinimide (NHS)-activated affinity column was used ( $\mathrm{Hi}$ trap, $5 \mathrm{ml} \mathrm{NHS}$-activated column; Amersham Pharmacia Biotech) to purify ACE from canine testicular tissue. The gel is based on highly cross-linked agarose beads with six-atom spacer arms attached to the matrix by epichlorohydrine and activated by $\mathrm{N}$-hydroxysuccinimide. The substitution level is $10 \mu \mathrm{mol} \mathrm{NHS}$ groups $\mathrm{ml}^{-1}$ gel.

Lisinopril coupling using an NHS-activated column. The ligand (lisinopril, $5 \mathrm{mmol} \mathrm{I}^{-1}$ ) was dissolved in a coupling buffer $\left(0.2 \mathrm{~mol} \mathrm{NaHCO}_{3} \mathrm{I}^{-1}, 0.5 \mathrm{~mol} \mathrm{NaCl} \mathrm{I}{ }^{-1}, \mathrm{pH} 8.3\right)$ to a concentration of $2 \mathrm{mg} \mathrm{ml}^{-1}$. Any excess active groups not coupled to the ligand were washed and inactivated according to the manufacturer's protocol. The column was then stored in a neutral pH buffer (Tris buffer, $\mathrm{pH}$ 7.4).
Purification. The column was equilibrated using a loading buffer containing $20 \mathrm{mmol}$ Tris $\mathrm{I}^{-1}, 0.3 \mathrm{~mol} \mathrm{NaCl} \mathrm{I}^{-1}$ and $0.1 \%(\mathrm{v} / \mathrm{v})$ Triton-X100, $\mathrm{pH}$ 8.0. The detergent-extracted testicular sample (20-40 mg protein) was applied to the $5 \mathrm{ml}$ column of affinity gel $3-5$ times at $22^{\circ} \mathrm{C}$ and washed with 3-4 bed volumes of loading buffer at 1 drop $\mathrm{s}^{-1}$. Elution was done with $2-3$ bed volumes of $50 \mathrm{mmol}$ sodium borate $\mathrm{I}^{-1}, \mathrm{pH}$ 9.0, modified from Pantaliano et al. (1984). Fractions were collected in $1.5 \mathrm{ml}$ volume and monitored by spectrophotometry $\left(A_{280}\right)$. The fractions were concentrated using amicon concentrators (molecular mass cut off $=$ $10 \mathrm{kDa})$ for the enzyme assay.

\section{ACE assay}

ACE activity was determined via an enzyme kinetic assay based on the hydrolysis of $1.5 \mathrm{mmol}$ Fa-Phe-Gly-Gly $\mathrm{I}^{-1}$ (FAPGG) buffered at $\mathrm{pH} 7.5$ with $50 \mathrm{mmol}^{\text {Tris } \mathrm{I}^{-1} \text { and }}$ $0.3 \mathrm{~mol} \mathrm{NaCl} \mathrm{I-1}$ in a microtitre plate assay (at $330 \mathrm{~nm}$ ) during an $8 \mathrm{~min}$ incubation. This assay is based on changes in the visible region of the substrate absorption spectrum that occur on hydrolysis of the furanacryloyl tripeptides (Holmquist et al., 1979; Pantaliano et al., 1984).

\section{Electrophoresis and immunoblotting}

The detergent extracts and purified concentrated fractions were solubilized in SDS and subjected to SDS-PAGE in $12 \%(\mathrm{w} / \mathrm{v})$ gels followed by silver staining or western blotting. Standard western blotting procedures were used (Towbin et al., 1979). Blots were incubated with an anti-ACE polyclonal antibody (1:5000). Anti-ACE is an antiserum raised against a $70 \mathrm{kDa}$ protein from the periacrosomal plasma membrane of equine spermatozoa which showed homology to ACE based on microsequence analysis of a peptide fragment (Dobrinski et al., 1997). After washing and incubation with a horseradish peroxidaseconjugated secondary antibody, the proteins were detected with enhanced chemiluminescence (ECL).

\section{Effect of ACE inhibitors and thiol reagents on ACE activity}

The preloaded sample and purified active fractions were incubated in the presence of an ACE inhibitor captopril $\left(10 \mu \mathrm{mol} \mathrm{I}^{-1}\right)$ for $30 \mathrm{~min}$. N-ethylmaleimide $\left(500 \mu \mathrm{mol} \mathrm{I}^{-1}\right)$ was added for an additional $30 \mathrm{~min}$ to re-establish the enzyme activity and the ACE activity was measured.

\section{Effect of EDTA and zinc on ACE activity}

The testicular extracts were depleted of intrinsic metals by dilution with 10 volumes of $10 \mathrm{mmol}$ Hepes $\mathrm{I}^{-1}$, $20 \mathrm{mmol} \mathrm{NaCl} \mathrm{I}^{-1}, 10 \mathrm{mmol}^{\mathrm{EDTA} \mathrm{I}} \mathrm{I}^{-1}(\mathrm{pH} 7.0)$. After $3 \mathrm{~h}$ at $22^{\circ} \mathrm{C}$, the EDTA-treated samples were dialysed with stirring at $4^{\circ} \mathrm{C}$ against 100 volumes of $10 \mathrm{mmol}$ sodium Hepes $\mathrm{I}^{-1}$, $20 \mathrm{mmol} \mathrm{NaCl} \mathrm{I}^{-1}$ ( $\mathrm{pH}$ 7.0). The dialysate was exchanged five times at $12 \mathrm{~h}$ intervals to remove excess EDTA. As a 
control, a second portion of the purified samples was diluted in the same buffer without EDTA. The concentrated samples were treated with zinc acetate at $1 \mathrm{mmol} \mathrm{I}^{-1}$ (final concentration) for $1 \mathrm{~h}$. After a 60 min incubation with zinc acetate, the ACE activity of the samples was determined again.

\section{Immunocytochemical localization of ACE in dog spermatozoa}

Ejaculated dog spermatozoa were diluted in Tyrode's albumin lactate pyruvate (TALP) containing 1\% (w/v) BSA, washed by centrifugation at $300 \mathrm{~g}$ for $10 \mathrm{~min}$, and resuspended at $5.0 \times 10^{6}$ cells $\mathrm{ml}^{-1}$. The washed spermatozoa were incubated with anti-ACE antibody (1:100 in PBS) for 60 min at $4^{\circ} \mathrm{C}$, washed with PBS (three $X$ $5 \mathrm{~min}$ ), and blocked with 5\% BSA-PBS (two $\times 5$ min), before incubation with secondary antibody, FITC-conjugated goat-anti-rabbit IgG, for 30 min (1:40 in PBS). The samples were then washed twice in PBS and mounted with 1,4diazabicyclo-[2.2.2] octane (DABCO), covered with a coverslip, sealed and examined at $\times 400$ magnification with an epifluorescence microscope. Control experiments were run with secondary antibody only or replacement of primary antibody with rabbit non-immune serum.

\section{Immunohistochemical localization of ACE in canine testis}

The testes of adult dogs $(n=3)$ were fixed in $4 \%(\mathrm{v} / \mathrm{v})$ paraformaldehyde, put through a series of graded ethanol incubations, embedded in paraffin wax and cut into $5 \mu \mathrm{m}$ sections. The tissue sections were deparaffinized and hydrated through xylenes and a graded ethanol series. Immunoperoxidase staining was performed with the vectastain ABC-Elite kit (Vector labs, Burlingame, CA). The sections were incubated for $30 \mathrm{~min}$ in $0.3 \%(\mathrm{v} / \mathrm{v})$ $\mathrm{H}_{2} \mathrm{O}_{2}$-methanol to quench endogenous peroxidase activity. After a wash in PBS-0.3\% (v/v) Triton-X100, the sections were incubated for 20 min with diluted blocking serum, washed and incubated with the anti-ACE antibody $(1: 200)$ overnight at $4^{\circ} \mathrm{C}$. The sections were incubated for 30 min with biotinylated horseradish peroxidase-linked secondary antibody $(1: 200)$ followed by incubation in $A B C$ reagent. The sections were then developed with the substrate 3 amino- 9 ethylcarbazole (AEC) according to the manufacturer's instructions. The sections were counterstained with haematoxylin. Normal rabbit serum was used as a negative control.

\section{Statistical analysis}

Data were analysed by analysis of variance (ANOVA; StatView, Cary, NC). Differences between treatments were assessed with Fisher's protected least significant difference test (StatView). The level of significance was $P<0.05$. Results are expressed as mean $\pm \mathrm{SE}$.

\section{Results}

\section{Affinity chromatography}

The total enzyme activity in the recovered purified fractions represented $72.1 \%$ of total activity loaded onto the lisinopril column. Most of the enzyme activity appeared between fraction 3 and fraction 5 (Fig. 1). The ACE activity in the starting material, based on hydrolysis of FAPGG, was $3.53 \pm 0.99 \mathrm{mU} \mathrm{mg}^{-1}$ protein, and there was a 1588 times enrichment in ACE activity after lisinopril affinity chromatography $\left(4139 \pm 2610 \mathrm{mU} \mathrm{mg}^{-1}\right.$ protein). Onedimensional PAGE and silver staining of the affinity-purified enzyme revealed a single protein of approximately $70 \mathrm{kDa}$ (Fig. 2).

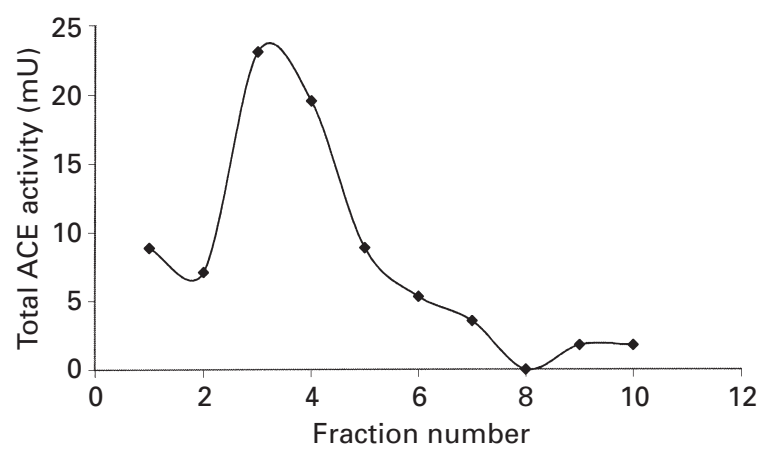

Fig. 1. Elution profile for angiotensin-converting enzyme (ACE) recovered after lisinopril affinity chromatography of detergentextracted dog testicular tissue. Fractions were collected in $1.5 \mathrm{ml}$ and concentrated in amicon concentrators for the ACE assay. (a)

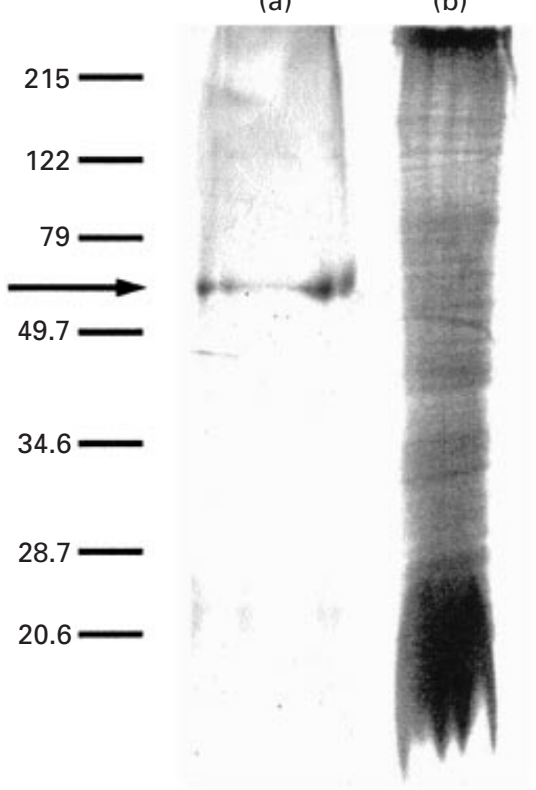

Fig. 2. Silver staining of (a) a purified fraction eluted from the lisinopril affinity column and (b) detergent-extracted dog testicular tissue. The samples were subjected to electrophoresis on a $12 \%$ (w/v) SDS-polyacrylamide gel. Arrow indicates a $65-70 \mathrm{kDa}$ protein. 
(a)

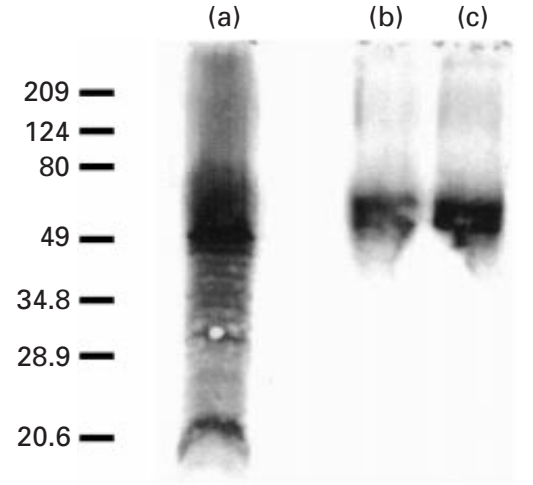

Fig. 3. Immunoblot of (a) detergent-extracted dog testicular tissue (this sample showed some proteolytic degradation) and of the purified (b) fraction 3 and (c) fraction 4 eluted from the lisinopril affinity column, using an anti-angiotensin-converting enzyme antibody (1:5000). A 65-70 kDa protein is visible.

\section{Immunodetection of ACE in dog testis and mature spermatozoa}

The anti-ACE antibody recognized a $65 \pm 5 \mathrm{kDa}$ protein in the detergent-extracted testicular tissue as well as in the purified fractions (Figs 3 and 4a). This antibody was generated against a $70 \mathrm{kDa}$ protein from the periacrosomal plasma membrane of equine spermatozoa. In ejaculated spermatozoa, immunoblotting with anti-ACE revealed a single protein of similar molecular mass (Fig. 4b).

\section{Effect of captopril and $\mathrm{N}$-methylmaleimide on ACE activity}

The ACE activity in these detergent extracts was inhibited significantly $(P<0.05)$ by $10 \mu \mathrm{mol}$ captopril $\mathrm{I}^{-1}$ (Fig. 5a). ACE activity was restored to $88 \%$ of normal activity by addition of the thiol-alkylating agent $\mathrm{N}$-methylmaleimide in the detergent extract samples preincubated with captopril (Fig. 5a). The ACE activity in the detergent extracts treated with captopril and $\mathrm{N}$-methylmaleimide was also significantly higher than ACE activity in detergent extracts treated with captopril only $(P<0.05)$. There was also activity in the affinity-purified fractions that was inhibited in the presence of captopril. The ACE-specific activity was restored to $50-89 \%$ of normal activity in the presence of $0.5 \mathrm{mmol} \mathrm{N}$-methylmaleimide $\mathrm{I}^{-1}$ in the affinity-purified fractions preincubated with captopril (Fig. 5b).

\section{Effect of EDTA and zinc on ACE activity}

Treatment of the testicular extracts with 10 mmol EDTA $\mathrm{I}^{-1}$ decreased the activity of ACE significantly $(P<0.002$; Fig. 6). ACE activity was restored almost fully in the presence of zinc $\left(5.28 \pm 0.73 \mathrm{mU} \mathrm{mg}^{-1}\right.$ protein) and was significantly higher than ACE activity in cells treated with EDTA only $(P<0.002$; Fig. 6).
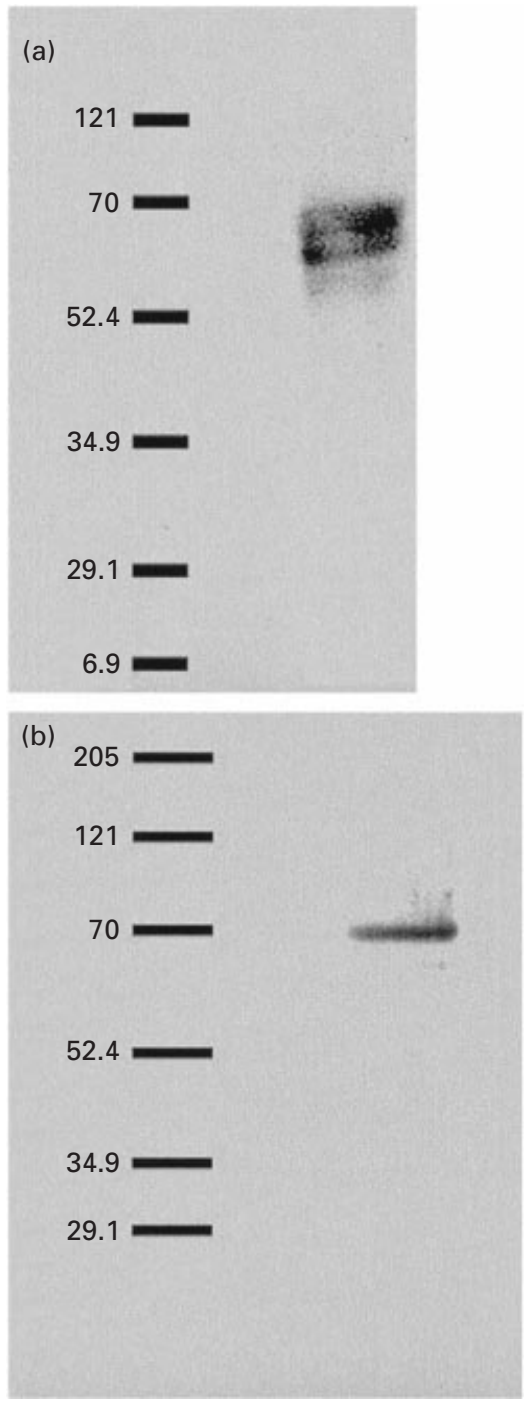

Fig. 4. Immunoblot of (a) detergent-extracted dog testicular tissue and (b) mature spermatozoa using an anti-angiotensin-converting enzyme antibody (1:5000). A 65-70 kDa protein is visible in both samples.

\section{Immunocytochemistry of dog spermatozoa}

There was intense punctate staining over the entire periacrosomal area of ejaculated spermatozoa (Fig. 7). The control experiments run with secondary antibody only or replacement of primary antibody with rabbit non-immune serum did not show any staining (data not shown).

\section{Immunohistochemistry of dog testis}

Abundant staining was observed in the adluminal region of the seminiferous tubules corresponding to the spermatids (Fig. 8a). The staining was localized to the Golgi region in the caudal portion of the cytoplasm in the late spermatids. No staining was observed in the control (Fig. 8b). 

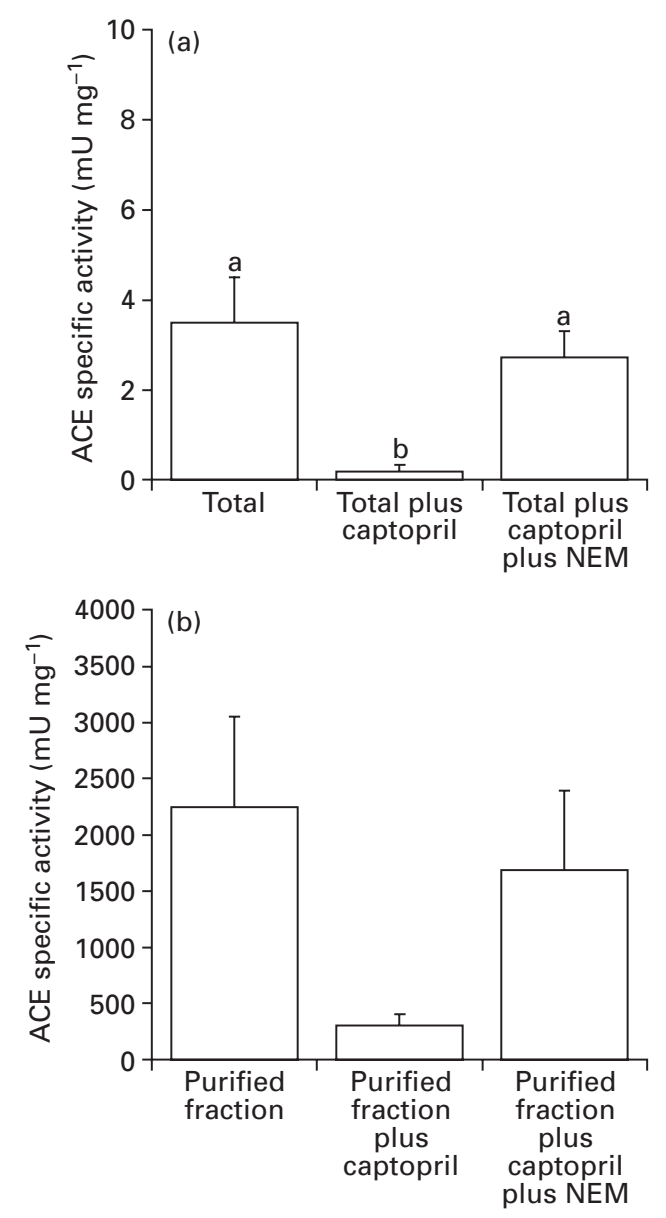

Fig. 5. Specific angiotensin-converting enzyme (ACE) activity of (a) dog testicular extracts and (b) pooled purified fractions eluted from the lisinopril column $(n=3)$. The preloaded sample and purified active fractions were incubated in the presence of an ACE inhibitor, captopril $\left(10 \mu \mathrm{mol} \mathrm{I}^{-1}\right)$ for $30 \mathrm{~min}$ followed by $\mathrm{N}$ ethylmaleimide (NEM; $500 \mu \mathrm{mol} \mathrm{I}^{-1}$ ) for an additional $30 \mathrm{~min}$ to reestablish the enzyme activity. The specific ACE activity was then measured using the Fa-Phe-Gly-Gly assay. abDifferent letters indicate significant differences between treatments $(P<0.05)$.

\section{Discussion}

ACE, which plays a central role in the renin-angiotensin system, has been described in a variety of tissues and organs. Cushman and Chang (1971) first reported ACE in the reproductive tract in rats and El-Dorry et al. (1982) reported ACE in the reproductive tract of rabbits. In the present study, the expression of ACE in canine testis and spermatozoa is described. ACE in canine testis has an apparent molecular mass of approximately 65-70 kDa. In contrast, a molecular mass of $90-110 \mathrm{kDa}$ has been reported for testicular ACE in mice, rats, rabbits, men (EIDorry et al., 1982; Ehlers et al., 1989; Langford et al., 1993) and rams (Gatti et al., 1999). These differences may be due to differences in glycosylation. El-Dorry et al. (1982)

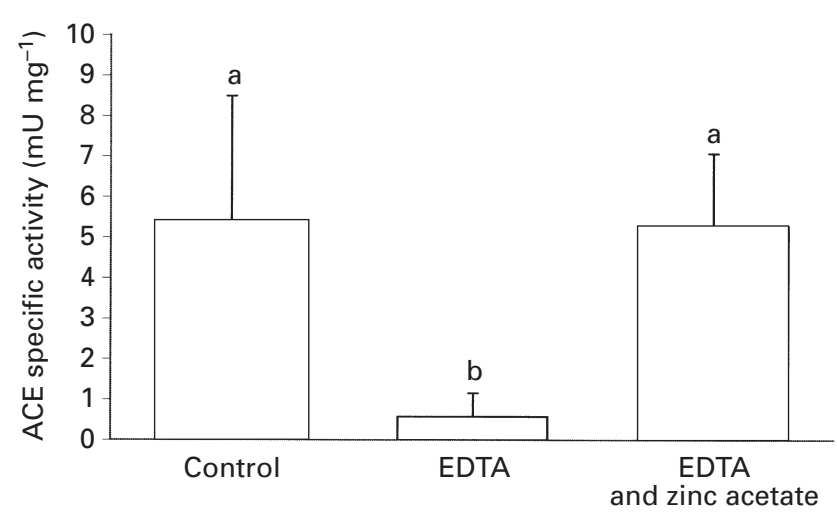

Fig. 6. Specific angiotensin-converting enzyme (ACE) activity of six dog testicular extracts. The testicular extracts were depleted of intrinsic metals by dilution with ten volumes of $10 \mathrm{mmol}^{\mathrm{Hepes}} \mathrm{I}^{-1}$, $20 \mathrm{mmol} \mathrm{NaCl} \mathrm{I}^{-1}, 10 \mathrm{mmol}^{\mathrm{EDTA} \mathrm{I}}{ }^{-1}$ (pH 7.0). Excess EDTA was removed by dialysis. The concentrated samples were then treated with zinc acetate at $1 \mathrm{mmol} \mathrm{I}^{-1}$ (final concentration) for $1 \mathrm{~h}$. After 60 min incubation with zinc acetate, the ACE activity of the samples was determined using a Fa-Phe-Gly-Gly assay. ${ }^{\text {ab Different }}$ letters indicate significant differences between treatments $(P<0.05)$.

showed that the carbohydrate component of the testicular enzyme accounts for about $20 \%$ of the total mass of the enzyme, and the carbohydrate portion may account for the difference in molecular mass between these species. This finding may explain the lower molecular mass of canine ACE estimated by western blotting in the present study.

Two forms of ACE have been described: the somatic form with a higher molecular mass (150-180 kDa) present in somatic tissues, including the epididymal epithelium and prostate; and the testicular form of a smaller size (90-110 kDa), which is expressed exclusively in germ cells. Earlier studies have suggested that the testicular enzyme is not generated after translation of the somatic enzyme by proteolysis (El-Dorry et al., 1982) and that its smaller size may be attributed to differences in the transcription of the same gene. More recent studies have shown that the gene encoding ACE is composed of two homologous regions and codes for both the somatic and testis isoenzyme (Sibony et al., 1993). The somatic form consists of two homologous catalytic domains ( $\mathrm{N}$ - and C-terminal domains). The testicular form is restricted to the C-terminal domain generated by the activity of a testis-specific promoter located within the twelfth intron of the somatic gene. In the present study, isolation of ACE from canine testis by lisinopril affinity chromatography yielded a single protein of $65-70 \mathrm{kDa}$, which was recognized by an antibody generated against equine testis ACE (Dobrinski et al., 1997). This protein appeared consistent with the testis isoform of ACE. ACE appears to be present in canine testis as well as in ejaculated spermatozoa. Some studies have shown that the presence of ACE in the testis and the epididymis appears to 


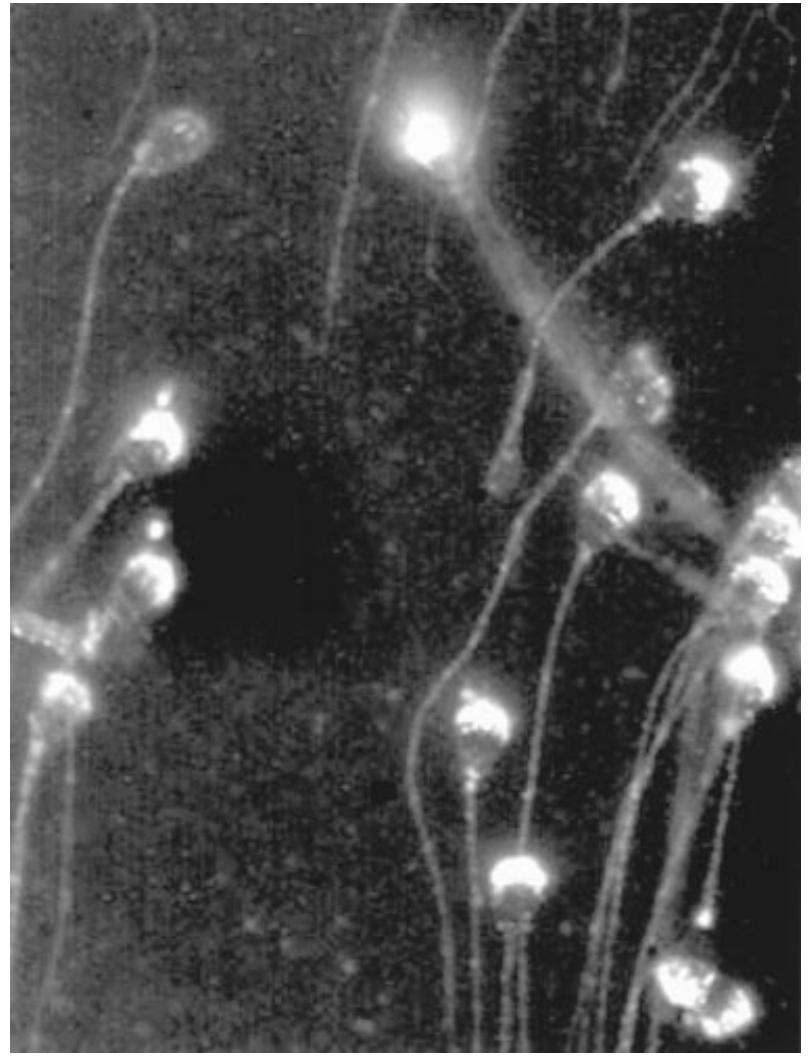

Fig. 7. Immunocytochemistry of dog spermatozoa. Ejaculated dog spermatozoa were diluted in TALP-1\% (w/v) BSA and were washed by centrifugation at $300 \mathrm{~g}$ for $10 \mathrm{~min}$ and resuspended at $5.0 \times 10^{6}$ cells $\mathrm{ml}^{-1}$. Washed spermatozoa were incubated with anti-angiotensin-converting enzyme antibody (1:100 in PBS) then incubated with secondary antibody, fluorescein isothiocyanateconjugated goat anti-rabbit IgG for $1 \mathrm{~h}$ (1:40 in PBS). Samples were examined at $\times 400$ magnification with an epifluorescence microscope.

be correlated with the appearance of spermatozoa (Jaiswal et al., 1984, 1985). Enzyme activity is low in immature animals and increases with the onset of puberty (Jaiswal et al., 1983). Wong and Uchendu (1990) proposed that this enzyme may participate, through angiotensin II activation, in the regulation of electrolyte and fluid transport in the epididymis, acting locally on a renin-angiotensin system in the epididymis. In addition, the presence of physiological substrates in the follicular fluid indicates that this enzyme may also regulate reproductive function in the female genital tract (Speth et al., 1999).

The protein was localized to the periacrosomal area of ejaculated spermatozoa by immunocytochemistry. In the testis, ACE was localized mainly in the adluminal region of the seminiferous tubules corresponding to the spermatids. This finding confirms earlier studies of ACE localization in rabbits (Berg et al., 1986), mice and rats (Langford et al., 1993; Sibony et al., 1994). Other studies have shown the presence of ACE over the entire periacrosomal area of
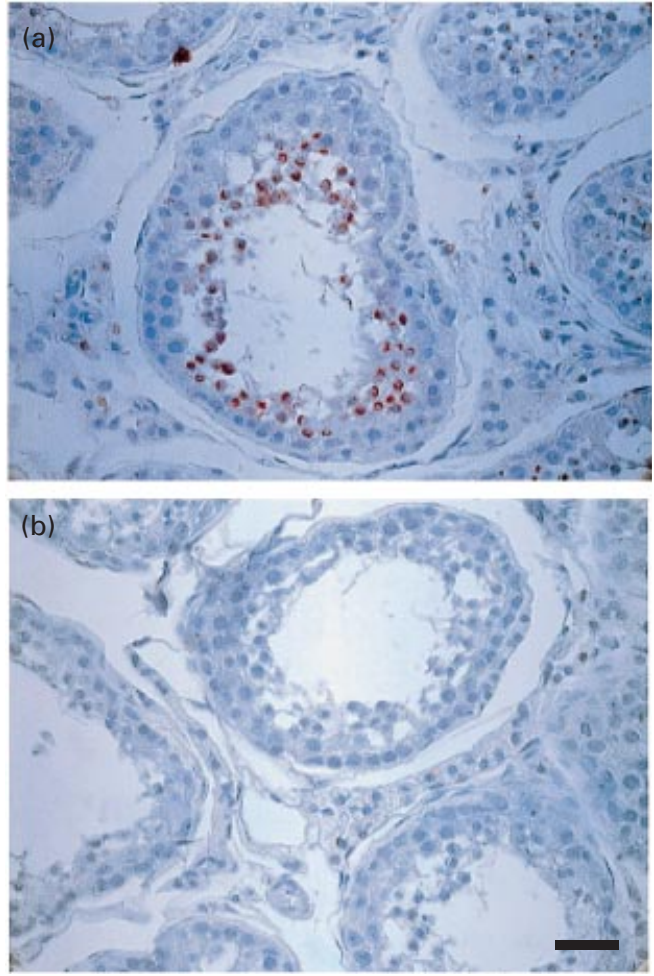

Fig. 8. Immunohistochemistry of dog testis. Immunoperoxidase staining was performed with the vectastain ABC-Elite kit. The sections were incubated with (a) anti-angiotensin-converting enzyme antibody $(1: 200)$ or (b) control rabbit serum overnight at $4^{\circ} \mathrm{C}$. The sections were then incubated for $30 \mathrm{~min}$ with diluted biotinylated horseradish peroxidase-linked secondary antibody $(1: 200)$ followed by incubation in $A B C$ reagent and were developed with 3 amino-9 ethylcarbazole (AEC). The sections were counterstained quickly with haematoxylin. Scale bar represents $30 \mu \mathrm{m}$.

equine spermatozoa (Dobrinski et al., 1997), in pig and sheep spermatozoa (Boettger et al., 1993), in human spermatozoa (Kohn et al., 1998), in the cytoplasm and cytoplasmic droplets of pig and human spermatozoa (Brentjens et al., 1986; Foresta et al., 1987) and in the acrosomal area of rat, mice and human spermatids (Strittmatter et al., 1985; Vivet et al., 1987; Sibony et al., 1994). Langford et al. (1993) showed that although testis ACE was first detected in step 10 spermatids in mice, testis mRNA was detected in younger cell populations, including late pachytene spermatocytes (Langford et al., 1993). Similarly, Sibony et al. (1994) showed that in mice and rats testicular ACE mRNA and its gene product were present only after completion of meiosis, with maximum expression during the acrosome phase. Similar to findings in other species, the results of the present study have confirmed the presence of ACE in canine spermatids and ejaculated spermatozoa.

The physiological significance of ACE in spermatozoa is 
not well understood, although it is proposed that ACE may have a role in capacitation (Foresta et al., 1987; Kohn et al., 1995). Many potential substrates for ACE, such as bradykinin, affect sperm function (Schill and Miska, 1992; Heder et al., 1994). An influence in motility has been proposed but the available data are contradictory. Bradykinin has been shown to promote sperm motility (Heder et al., 1994). In contrast, long-term treatment of men with captopril, a specific ACE inhibitor, did not have any effect on sperm motility. The importance of ACE in spermatozoa is illustrated further by reports of reduced fertility in male ACE knock-out mice, whereas female ACE knock-out mice have normal fertility (Krege et al., 1995; Esther et al., 1996; Hagaman et al., 1998). These studies showed that expression of ACE in spermatozoa is important for fertilization and that spermatozoa lacking ACE show defects in transport within the oviducts and in binding to zonae pellucidae. Further studies need to address the physiological significance of ACE in sperm function and fertility, and the role of the renin-angiotensin system in male reproductive function.

In the present study, biochemical characterization of canine testis ACE was based on a lisinopril affinity column to purify ACE from canine testicular tissue. Affinity resins for ACE isolation have been used previously and partial purification of ACE has been achieved with several types of ligands. Multi-step protocols have been replaced progressively by simpler and less laborious chromatography procedures using an affinity gel with the potent converting enzyme inhibitor lisinopril (Lanzillo et al., 1980, 1985). The agarose gel affinity chromatography with lisinopril as a ligand has been used by other laboratories too (El-Dorry et al., 1982; Bull et al., 1985; Hooper and Turner, 1987). Although the commercially available small column used in the present study is not suited for large-scale purification owing to its small capacity and its small size spacer, it provided a convenient way to characterize the canine enzyme in a simplified protocol. In the present study, sodium borate ( $\mathrm{pH}$ 9.0) was used to recover the activity in the purified fractions without the need to include an inhibitor in the elution buffer and without the need for extensive dialysis while maintaining enzyme activity after the elution. The methodology described provided a simplified protocol for the isolation and enrichment of ACE from canine testis.

Both the testicular extracts and the purified fractions were inhibited by captopril at $10 \mu \mathrm{mol} \mathrm{I}^{-1}$. In our preliminary studies, ACE activity was inhibited by captopril between $1 \mu \mathrm{mol} \mathrm{I} \mathrm{I}^{-1}$ and $100 \mu \mathrm{mol} \mathrm{I} \mathrm{I}^{-1}$ (data not shown). Captopril is an aliphatic thiol-derivative, which acts as a ligand for the central zinc atom of the ACE molecule, thus inhibiting specifically the attachment of the enzyme to its substrate (Krassnigg et al., 1986). This ACE-specific inhibitor, which contains a sulphydryl group, is a potent antihypertensive drug. It exerts its action by inhibiting the generation of angiotensin II.

In the present study, the activity of ACE was re- established to $88 \%$ of normal activity in the presence of $\mathrm{N}$ ethylmaleimide, which quenches the sulphydryl group of captopril by alkylation (Lanzillo et al., 1985).

The role of zinc in ACE activity was also confirmed in the present study. Successful reactivation of metal-depleted ACE by zinc provided evidence that ACE requires zinc to be fully active, but it does not rule out the role of other metals in ACE activity. Ehlers and Riordan (1991) have characterized the zinc and binding stoichiometries in both ACE somatic and testis isozymes. Rahman et al. (1999) also observed a reduction in ACE activity in rat atrophied testis as a result of zinc deficiency. Together, these studies support the importance of zinc in the activity of ACE.

The results of the present study provide evidence that ACE is present in canine testis in spermatids and spermatozoa. ACE retains its activity after purification by lisinopril affinity chromatography. Activity of canine ACE is inhibited by captopril and EDTA and is restored in the presence of $\mathrm{N}$-ethylmaleimide and zinc.

This work was supported by the Kenneth A. Scott Charitable Trust, a Keybank Trust.

\section{References}

Berg T, Sulner J, Lai CY and Soffer RL (1986) Immunohistochemical localization of two angiotensin I-converting enzymes in the reproductive tract of the male rabbit Journal of Histochemistry and Cytochemistry 34 753-760

Boettger A, Kertscher U, Steinmann C, Baeger U, Siems W-E and Heder G (1993) Degradation of bradykinin in semen of ram and boar Biochemical Pharmacology 45 1983-1988

Brentjens JR, Matsuo S, Andres GA, Calwell PRB and Zomboni L (1986) Gametes contain angiotensin-converting enzyme (kininase II) Experientia 42 399-402

Bull HB, Thornberry NA and Cordes EH (1985) Purification of angiotensinconverting enzyme from rabbit lung and human plasma by affinity chromatography Journal of Biological Chemistry 260 2963-2972

Cushman DW and Chang HS (1971) Concentrations of angiotensinconverting enzyme in tissues of the rat Biochimic et Biophysica Acta $250261-265$

Dobrinski I, Ignotz GG, Fagnan MS, Ashley IY and Ball B (1997) Isolation and characterization of a protein with homology to angiotensin converting enzyme from the periacrosomal plasma membrane of equine spermatozoa Molecular Reproduction and Development 48 251-260

Ehlers MRW and Riordan JF (1991) Angiotensin-converting enzyme: zinc and inhibitor-binding stoichiometries of the somatic and testis isozymes Biochemistry $307118-7126$

Ehlers MRW, Fox EA, Strydom DJ and Riordan JF (1989) Molecular cloning of human testicular angiotensin-converting enzyme: the testis isozyme is identical to the C-terminal half of endothelial angiotensinconverting enzyme Proceedings National Academy of Sciences USA 86 7741-7745

El-Dorry HA, Bull HG, Iwata K, Thornberry EH and Soffer RL (1982) Molecular and catalytic properties of rabbit testicular dipeptidyl carboxypeptidase Journal of Biological Chemistry 257 14128-14133

Esther CR, Howard TE, Marino EM, Goddard JM, Capecchi MR and Bernstein KE (1996) Mice lacking angiotensin-converting enzyme have low blood pressure, renal pathology, and reduced male fertility Laboratory Investigation 74 953-965

Esther CR, Marino EM, Howard TE, Machaud A, Corvol P, Capecchi MR and Bernstein KE (1997) The critical role of tissue angiotensinconverting enzyme as revealed by gene targeting in mice Journal of Clinical Investigation 99 2375-2385 
Foresta C, Indino M, Manoni F and Scandellari C (1987) Angiotensinconverting enzyme content of human spermatozoa and its release during capacitation Fertility and Sterility 47 1000-1003

Gatti JL, Druart X, Guerin Y, Dacheux F and Dacheux JL (1999) A 105 to 94 kilodalton protein in the epididymal fluids of domestic mammals is angiotensin-converting enzyme (ACE); evidence that sperm are the source of ACE Biology of Reproduction $60937-945$

Hagaman JR, Moyer JS, Bachman ES et al. (1979) A continuous spectrophotometric assay for angiotensin converting-enzyme Analytical Biochemistry 95 540-548

Heder G, Bootger A, Siems We, Rottman M and Kertscher U (1994) The enzymatic degradation of bradykinin in semen of various species Andrologia 26 295-301

Hooper NM and Turner AJ (1987) Isolation of two differentially glycosylated forms of peptidyl peptidase A (angiotensin converting enzyme) from pig brain; a re-evaluation of their role in neuropeptide metabolism Biochemical Journal 241 625-633

Jaiswal AK, Panda JN, Kumar MV and Singh LN (1983) Age related development of angiotensin converting enzyme in testis and epididymis of rat Andrologia 15 347-349

Jaiswal A, Joshi P, Kumar MV, Panda JN and Singh LN (1984) Angiotensin converting enzyme in the testis and epididymis of mammals Andrologia $16410-416$

Jaiswal AK, Panda JN, Kumar MV and Joshi P (1985) Androgen dependence of testicular and epididymal angiotensin converting enzyme Andrologia 17 92-97

Kohn FM, Miska W and Schill WB (1995) Release of angiotensin-converting enzyme from human spermatozoa during capacitation and acrosome reaction Journal of Andrology 16 259-265

Kohn FM, Dammshauser I, Neukamm C, Renneberg H, Siems WE, Schill WB and Aumuller G (1998) Ultrastructural localisation of angiotensinconverting enzyme in ejaculated spermatozoa Human Reproduction $\mathbf{1 3}$ 604-610

Krassnigg F, Niederhauser H, Placzek R, Frick J and Schill WB (1986) Investigations on the functional role of angiotensin converting enzyme (ACE) in human seminal plasma Advances in Experimental Medicine and Biology 198 477-485

Krege JH and O'Brien DA (1998) Angiotensin-converting enzyme and male fertility Proceedings National Academy of Sciences USA 95 2552-2557

Krege JH, John SWM, Langenbach LL, Hodgin JB, Hagaman JR, Bachman ES, Jennette JC, O'Brien DA and Smithies O (1995) Male-female differences in fertility and blood pressure in ACE-deficient mice Nature 375 146-148

Langford KG, Zhou Y, Russell LD, Wilcox IN and Bernstein K (1993) Regulated expression of testis angiotensin converting enzyme during spermatogenesis in mice Biology of Reproduction 48 1210-1218

Lanzillo JJ, Polsky-Cynkin R and Fanburg BL (1980) Large scale purification of angiotensin converting enzyme from human plasma utilizing an immunoadsorbent affinity gel Analytical Biochemistry 103 400-407

Lanzillo JJ, Stevens J, Dasarathy Y, Yotsumoto H and Fandburg BL (1985 Angiotensin-converting enzyme from human tissues 260 14938-14944

Pantaliano MW, Holmquist B and Riordan JF (1984) Affinity chromatography purification of angiotensin-converting enzyme Biochemistry 23 1037-1042

Rahman AS, Kimura M and Itokawa Y (1999) Testicular atrophy, zinc concentration and angiotensin-converting enzyme activity in the testes of vitamin A-deficient rats Biological Trace Element Research 67 29-36

Schill WB and Miska W (1992) Possible effects of the kallikrein-kenin system on male reproductive functions Andrologia 24 69-75

Sibony M, Gask JM, Soubrier F, Alheno-Gelas F and Corvol P (1993) Gene expression and tissue localization of the two isoforms of angiotensin converting enzyme Hypertension 21 827-835

Sibony M, Segretain D and Gasc JM (1994) Angiotensin-converting enzyme in murine testis: step-specific expression of the germinal isoform during spermiogenesis Biology of Reproduction 50 1015-1026

Speth RC, Daubert DL and Grove KL (1999) Angiotensin II: a reproductive hormone too? Regulatory Peptides 79 25-40

Strittmater SM, Thiele EA, DeSouza Eb and Snyder SH (1985) Angiotensin converting enzyme in the testis and epididymis; differential development and pituitary regulation Endocrinology 117 1374-1379

Vivet F, Callard P and Gamoudi A (1987) Immunolocalization of angiotensin 1 converting enzyme in the human genital tract by the avidin-biotin complex method Histochemistry 86 499-502

Wong PYD and Uchendu CN (1990) The role of angiotensin-converting enzyme in the rat epididymis Journal of Endocrinology 125 457-465

Received 9 October 2000

First decision 4 December 2000.

Revised manuscript received 1 March 2001.

Accepted 27 March 2001 